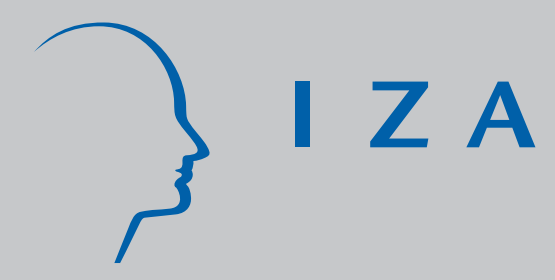

IZA DP No. 2253

Performance Pay and Earnings:

Evidence from Personnel Records

Tuomas Pekkarinen

Chris Riddell

August 2006 


\title{
Performance Pay and Earnings: Evidence from Personnel Records
}

\author{
Tuomas Pekkarinen \\ Uppsala University \\ and IZA Bonn \\ Chris Riddell \\ Queen's University
}

\section{Discussion Paper No. 2253 \\ August 2006}

\author{
IZA \\ P.O. Box 7240 \\ 53072 Bonn \\ Germany
}

Phone: +49-228-3894-0

Fax: +49-228-3894-180

Email: iza@iza.org

Any opinions expressed here are those of the author(s) and not those of the institute. Research disseminated by IZA may include views on policy, but the institute itself takes no institutional policy positions.

The Institute for the Study of Labor (IZA) in Bonn is a local and virtual international research center and a place of communication between science, politics and business. IZA is an independent nonprofit company supported by Deutsche Post World Net. The center is associated with the University of Bonn and offers a stimulating research environment through its research networks, research support, and visitors and doctoral programs. IZA engages in (i) original and internationally competitive research in all fields of labor economics, (ii) development of policy concepts, and (iii) dissemination of research results and concepts to the interested public.

IZA Discussion Papers often represent preliminary work and are circulated to encourage discussion. Citation of such a paper should account for its provisional character. A revised version may be available directly from the author. 


\section{ABSTRACT \\ Performance Pay and Earnings: Evidence from Personnel Records}

This paper examines the effects of performance pay on earnings using linked employeeemployer panel data from Finland. These payroll data contain information on the exact share of earnings obtained and hours worked on a performance pay contract. Using these data, we estimate the effects of performance pay in the presence of both individual and firm-specific unobserved heterogeneity. Furthermore, we are able to estimate the effects of performance pay contracts in tasks of different complexity and for the subsample of workers who change jobs following an establishment closure. Unobservable firm characteristics explain $30-50 \%$ of the variance in performance pay. After controlling for unobservable individual and firm characteristics, performance pay workers earn substantially more than fixed rate workers. The effects persist when only workers who changed firms, and contracts, due to an establishment closure are used for identification. There is also a strong, negative relationship between job complexity and the incentive effects of performance pay. Finally, we exploit several 'natural experiments' where there was a compensation regime change in one plant of a given firm, but not in other plants. The plants are highly similar pre-regime change, and had a common trend in earnings pre-regime change. These experiments also yield substantial earnings premiums.

JEL Classification: J33, J41

Keywords: performance pay, piece rates, incentives

Corresponding author:

Tuomas Pekkarinen

Uppsala University

Department of Economics, Box 513

75120 Uppsala

Sweden

E-mail: tuomas.pekkarinen@nek.uu.se

\footnotetext{
* We thank seminar participants at the LSE, Oxford, MIT (Sloan), University of Minnesota (Carlson), University of Toronto, University of British Columbia, 2004 EALE meetings (Lisbon), 2006 SOLE meetings (Boston), and in particular Josh Angrist, Pablo Casas, Francis Kramarz, Steve Lehrer, Thomas Lemieux, and Paul Oyer for their helpful comments. The early drafts of this paper were written when Pekkarinen was at Nuffield College and Riddell was with TARGET at the University of British Columbia. The authors also thank the Confederation of Finnish Industry and Employers (Teollisuus ja työnantajat) for the permission to use their wage records. The data are archived at the Labour Institute for Economic Research, Helsinki, and the permission to use the data are controlled by the Confederation of Finnish Industry and Employers. Pekkarinen acknowledges the financial support of the Academy of Finland, Finnish Work Environment Fund and Yrjö Jahnsson Foundation. Riddell acknowledges the financial support of the Social Sciences and Humanities Research Council of Canada.
} 


\section{Introduction}

There is considerable interest in the link between performance pay and productivity. Prior to the 1990s, the empirical literature was quite weak: some studies were based on cross-sectional evidence, others were merely anecdotal. In recent years, several studies from the economics literature, and to a lesser extent, the management literature use longitudinal data from a single firm that changed its compensation policy to examine the effect of performance pay controlling for unobserved worker heterogeneity (e.g., Lazear 2000). A small group of other studies perform similar analyses by using large, household-based longitudinal surveys (e.g., Parent 1999).

Another small group of papers approach the issue by combining structural models with detailed longitudinal data from a single firm (e.g., Shearer 2004).

While this small but growing body of evidence has improved our understanding of the effects of performance contracts, they either focus on a very narrow set of individual firms and tasks, or ignore establishment level factors altogether. While there is clearly reason to be concerned about individual-specific unobserved heterogeneity - workers observed to be on performance pay contracts may be higher ability or more motivated - there is also reason to be concerned about the endogeneity of compensation policy - firms probably do not randomly decide to implement performance pay. If the firms changed compensation policies as a result of some unobserved changes that took place at the firm level then previous studies may have failed to identify the incentive effects of performance-based compensation policies.

In this paper, we use unique linked employer-employee panel data from Finland over 19902000 to estimate the effects of pay for performance contracts on earnings. These data contain yearly information on the exact share of earnings from a performance contract and cover the entire population of blue collar workers in the metal manufacturing sector. The linked employer- 
employee nature of the data allows us to estimate the effect of performance contracts controlling for both individual and establishment level fixed effects.

What distinguishes these data from those used in prior studies is that we have variation in payment schemes across both individuals and firms. We are thus able to estimate the effect of performance contracts separately for within firm changes and for changes that result from workers moving between firms. Furthermore, we can identify those workers who were forced to move firms as a result of an establishment closure. We argue that comparing workers who changed contracts following an establishment closure with those that did not is a more exogenous source of variation to exploit. As well, we find several "natural experiments" where there was a compensation regime change in one plant of a given firm but not in other plants. Finally, the institutional framework of this industry is such that we observe specific details on the complexity of all jobs. This allows us to estimate the effects of performance contracts across tasks of different complexity.

\section{Background}

The impact of performance pay on individuals and establishment outcomes has received considerable attention from both the economics and management disciplines. Most of the empirical literature consists of either detailed studies of a single firm, studies that use large household or establishment surveys (usually cross-sectional), or the filings from publicly traded companies (typically only the Fortune 500 or similar small subset). The economics literature has tended to focus on cases where individual contracts are observed - mainly piece rates - while the management literature has tended to focus on establishment-level compensation policies such as 
profit-sharing. ${ }^{2}$ Both fields also have a large set of executive compensation studies. The key finding of the economics literature is that contracts that make pay a function of worker output in particular piece rates - increase productivity and earnings relative to contracts that do not make pay a function of output. The evidence of productivity gains is much less compelling in the case of the executive compensation and profit-sharing literatures. A full review of the performance pay literature is beyond the scope of this paper, and so we focus on the piece rate studies in the economics literature which are the most comparable to our paper. Excellent reviews are provided by Gibbons and Waldman (1999) and Prendergast (1999).

A key problem with much of the performance pay literature is that compensation policy should likely not be viewed as exogenous. Firms that use performance pay are likely systematically different in unobserved ways that are correlated with observable firm (and worker) characteristics as well as outcomes such as productivity and profitability than firms that do not use performance pay. The same concept is likely true for employees as well - more able or more motivated workers may be more likely to accept (or be offered) a performance-related contract. A good deal of the performance pay literature ignores the selection issue, thereby assuming that firms (or individuals) which do not use performance pay can act as a comparison group for those that do (e.g., Seiler 1984; Brown 1992 or the papers in Ehrenberg 1990).

Some studies attempt to deal with the selection problem by collecting longitudinal data on workers from a firm or by using large, household longitudinal surveys such as the NLSY, PSID or BHPS , and then difference out unobserved individual-specific heterogeneity. Examples of survey-based longitudinal studies include Parent (1999; 2001) and Booth and Frank (1999). Key examples of the individual firm approach are Lazear's (2000) study of Safelite Glass, Shearer's

\footnotetext{
${ }^{2}$ One notable exception to this is Banker, Young, and Potter (1996). The authors study the effects of a bonus pay system in a retail trade establishment that implemented the policy in 15 of 34 outlets allowing for a natural experiment design.
} 
random assignment study on a British Columbia tree planting firm (2004), and the Bandiera, Barankay, and Rasul (2005) study of a U.K. fruit farm. The latter groups of studies have the distinct advantage of having information on actual worker productivity; all find very large productivity gains from piece rates relative to fixed wages, but also considerable support for selection bias. For instance, in Lazear (2000), the switch to piece rates increased productivity by about $40 \%$, only half of which was attributed to an incentive effect. In Shearer's experiment, productivity gains were about $20 \%$.

While recent econometric studies of individual firms have made a major advancement over the earlier performance pay literature, and provide compelling evidence of both the productivity gains from performance pay and of the role of selection bias, there are some drawbacks to them. First, they come from an incredibly narrow set of occupations. Second, each study is based on only a single firm. But, as noted above, just as we anticipate individual unobserved heterogeneity to be problematic in an individual-level study of performance pay, compensation policy at the firm level is likely endogenous as well. As discussed in the next section, theories of the firm's decision to use performance pay revolve around firm-specific factors such as monitoring costs and the composition of the workforce (for instance, skill heterogeneity). Abowd, Creecy and Kramarz (2002) show that failing to account for unobserved firm-specific factors can lead to substantial biases in the estimates on individual-level covariates. ${ }^{3}$ Survey-based longitudinal studies avoid the narrow occupation issue, but still ignore establishment characteristics, rarely have explicit information on contracts, and are subject to considerable measurement error. ${ }^{4}$

\footnotetext{
${ }^{3}$ This is also true for firm-level covariates (such as firm size) that are sometimes available in household surveys.

${ }^{4}$ For instance, in the NLSY, you observe whether the individual indicates they are paid by piece rates, but you do not observe the precise dollar amount received through performance pay nor the percentage of earnings attributable to a performance pay contract. With the personnel records we possess, the precise amount of performance pay income and share of performance pay hours is observed.
} 
This paper uses an empirical strategy that lies between the household survey approach and the detailed case study approach. In particular, we use unique linked employer-employee panel data to provide new evidence on the effects of performance pay on labour market outcomes in the presence of both individual-specific and firm-specific unobserved heterogeneity. This data is derived from payroll records, which in addition to being low measurement error allows us to observe the exact share of earnings and hours that an employee works on a performance pay contract. There are also three different types of contracts that can be studied. The data covers an eleven year period of an entire industry (metal manufacturing) of an entire country (Finland). Moreover, the institutional framework for this industry-country is such that we have richer information on employee characteristics than available in most personnel data, and very detailed and reliable information on job complexity. On the other hand, the data does not allow us to observe actual productivity, and thus we must test for productivity effects indirectly through examining earnings.

\section{Theoretical considerations}

The performance pay contracts in the Finnish metal industry for blue-collar workers are pure piece rates or a mixed piece rate/fixed rate contract, and thus we focus on theories relevant for these types of contracts. ${ }^{5}$ The institutional details on payment methods and wage determination in this industry are discussed in detail in section 4. Lazear's (1986) model is the benchmark for contracts that make pay a function of output, with subsequent reformulations by Brown (1990), Booth and Frank (1999), and Lazear (2000).

\footnotetext{
${ }^{5}$ Prendergast (1999) considers theoretical issues in other performance pay settings such as team-based performance pay, efficiency wages, and so forth.
} 
Lazear's two-period model is largely concerned with the sorting of workers between piece rate firms and fixed rates firms. Fixed rate workers are paid a salary, $S$, that is independent of productivity while piece rate workers are paid based on output (q), but must be monitored which incurs a cost, $M$, resulting in a piece rate wage of $q-M .{ }^{6}$ Workers know their own $q$ 's and choose the payment method that yields the highest earnings. Thus, workers will choose the piece rate firm iff $q-M>S$ while others choose the salary firm. Firms paying salaries therefore know that they have, on average, less productive employees and pay a salary based on the expected productivity of that subsample of workers. The key testable implication is that earnings should be higher for piece rates workers than fixed rate workers. ${ }^{7}$

Booth and Frank extend Lazear's model to a richer case where a) monitoring costs can differ across firms, and b) worker output is a function of both effort and ability where effort cannot be monitored and ability has two components: an observable part (subject to a monitoring cost), and an unobservable component. Lazear (2000) makes a similar extension in the case of a single firm (and thus ignores monitoring costs). Both of these theories yield the same conclusion that earnings for piece rate workers will be higher than fixed rate workers, but unlike Lazear (1986), part of this earnings effect it due to selection on ability and part is due to an incentive to work harder. An interesting feature of these models is that, on average, effort need not be higher for piece rate workers because their higher ability means they do not have to exert as much effort for the same level of output. Effort should increase, however, if a given worker moves from a fixed rate to a piece rate. A further implication of Booth and Frank is that monitoring costs affect the

\footnotetext{
${ }^{6}$ This is in part because the firm must know their output to pay them, but could also be due to the quality control concerns with piece rate contracts.

${ }^{7}$ Lazear's theory is based on a zero-profit condition, and so salary firms have less productive workers, but this is exactly offset by savings on monitoring costs and a lower wage bill.
} 
firms’ decision to use performance-based pay. In general, piece rate jobs will be held by high ability workers in low monitoring cost firms.

\section{Data}

The data come from the records of the Confederation of Finnish Industry and Employers. They contain all payroll records including earnings and hours worked for all workers who are employed in firms affiliated with the Confederation. In the case of manufacturing in Finland, this covers virtually all firms - hence our focus on the manufacturing sector. We have access to yearly information on the blue-collar population of the metal industry from 1990 to $2000 .^{8}$ As will be discussed in more detail below, the metal industry is unique in that highly detailed and reliable information on job complexity is available. Each observation in our data contains the accumulated hours worked and earnings within the last quarter of each calendar year. After eliminating some observations due to missing information, we have a panel of 601,182 employee-year observations representing 120,128 workers from 602 firms. The average number of years of observations per worker is $5.5 .{ }^{9}$ Table 1 presents summary statistics on the key variables. In addition to the variables listed in Table 1, the data contains very rich information on the nature of the individual's job (discussed further below), as well as years of education beginning in 1996. Thus, individuals who permanently exit the data prior to 1996 have no education information. The results presented in the paper exclude education, but we replicate all

\footnotetext{
${ }^{8}$ Wage determinants and payment methods are very different for white-collar workers.

${ }^{9}$ A second sample will be used for the 1993 to 2000 period where we have additional information on the plant. If individual plants within firms have autonomy over compensation policy and other practices unobserved to us, it may be more appropriate to treat the plant as the 'firm unit' rather than the firm. For the 1993 to 2000 period, there are a total of 691 plants from 434 firms. Ultimately, using plants instead of establishments made no difference to the results and so for brevity these estimates are omitted.
} 
of our analysis for the 1996-2000 years including education and the results are virtually unchanged.

\subsection{Wage determination in the Finnish metal industry}

The Finnish metal industry is unionized with the general guidelines on wage determination set out in the collective agreement that is negotiated at a national level between the central employer organization and the trade union. The collective agreement indicates that wages should be determined according to the complexity of the job, and by various individual and firmspecific arrangements.

The collective agreement sets a job-specific minimum hourly wage, which is referred to as the occupation-related wage. These hourly wages are determined according to an evaluation of all jobs in the industry, which is conducted by a group of experts who assign complexity points to each job. The complexity level is based on three criteria: 1) how long does it take to learn the job; 2) the degree of responsibility in the job; and 3) the working conditions. The more demanding the job, the more complexity points it is assigned, and the higher the occupationrelated wage. There is a one-to-one correspondence from the complexity points to occupationrelated wages. The occupation-related wages can therefore be interpreted as a continuous variable that measures the complexity of the tasks. We observe the occupation-related wages, along with final wages, of each individual and their occupational codes (or more appropriately, their job assignment - 165 categories).

The role of the collective agreement is to set minimum standards for wage determination. A worker in this industry knows the minimum wage he is entitled to for his specific job. The determination of the final wage takes place at the establishment level (or possibly plant level). 
An individual firm is free to set wages as long as they stay above the minimum levels set by the collective agreement. Moreover, the payment method is decided by the firm.

\subsection{Payment schemes in the Finnish metal industry}

The collective agreement allows firms to choose from three different contracts: fixed rates with performance bonus, piece rates and reward rates. The spirit of the collective agreement is that the payment method should be determined by the characteristics of the tasks performed by the worker.

On fixed rates, workers are paid by the hour; however, fixed rate contracts have provisions for discretionary bonuses of $2 \%-17 \%$ of the occupation-related wage (i.e., the minimum wage for a given job). The bonus is based on the supervisor's evaluation of the employee. The collective agreement indicates that employers are to use the full range of bonus amounts, and to assign these bonuses such that they are distributed symmetrically around the mean of $9.5 \%$. We observe these bonuses in the data, and incorporate them into the earnings of fixed rate workers. For most jobs in this industry, there is considerable variation in fixed rate earnings with many fixed-rate workers earning in excess of the sum of the occupation-related wage and maximum bonus. This variation reflects firm-specific arrangements.

On piece rates, workers are paid purely based on individual output. The collective agreement indicates that piece rates should be used on clearly specified task assignments, and that payment should be based on output measures such as units, kilograms or meters produced. As well, total earnings for piece rate workers should not fall below the occupation-related wage, and thus firms should set the specific piece rate amount at a sufficiently high level. In fact, there are no piece rate workers in any year in the data with an actual hourly wage below the occupation-related 
threshold. On the other hand, there is no ceiling on the piece rate or hours worked. Piece rates are the least common payment scheme in the industry at only $10 \%$ of total hours worked.

The final compensation contract in this industry is reward rates, which are a mix of piece rates and fixed rates, and could also include a team-based bonus. Thus, a part of the wage is a fixed hourly amount, while a part is determined purely on individual-based output, and another part could be based on team output. Unfortunately, the payroll records from the Confederation do not separate the part of reward rate pay that was earned from output versus the part that was fixed. The exact share of output-determined (either individual or team) earnings may vary across firms and across tasks.

\subsection{The use of performance pay across firms and jobs}

A unique feature of the data is that we observe the exact share of hours that an individual works on a given contract. This information reveals that, for men, $39 \%$ of workers in this industry always worked on a fixed rate schedule (i.e. $100 \%$ of hours on a fixed rate contract), about $1 \%$ always worked on piece rates, and $10 \%$ always worked on reward rates. The numbers are very similar for women. Thus, for half of the blue-collar metal industry population, the incentive effect of performance pay cannot be estimated since the counterfactual is not observed. Also of note is that among the $50 \%$ of workers who experienced a change in their contract, many worked on different contracts within the same year. This is a unique form of variation that we exploit: some of the variation in contracts comes from individuals changing from a $100 \%$ fixed rate in year $t$ to a performance pay contract in year $t+1$ (and vice versa); some of the variation comes from individuals changing the mix of time spent on a fixed rate vs. performance pay contract in year $t$ to the mix of contracts in year $t+1$. Figure 1 plots the kernel estimate of the density of piece rate shares for men working some hours on a piece rate contract, while Figure 2 
plots the same for reward rates. The figures are very similar for women. It is clear that piece rate contracts are very different from reward rate contracts despite both making pay a function of output. Reward rates are rarely used in 'low doses'. For employees with positive reward rate use the strong majority work $100 \%$ of their hours on reward rates; in fact, the $25^{\text {th }}$ percentile of reward rate hours is .9. For piece rates there is a clear spike at 1 , but the distribution is very different; for instance, the $25^{\text {th }}$ percentile is only .37 .

To shed some more light on the firm's decision to use performance pay, we conduct a simple analysis of variance within each yearly cross-section. ${ }^{10}$ The results are reported in Table 3. In each cross-section, we regress the piece rate share, as well as the reward rate share, on firm dummies with and without individual and task characteristics. The second and third columns of Table 2 report their marginal contribution to the $\mathrm{R}^{2}$ of the model. The difference between the $\mathrm{R}^{2}$ of each set of dummies in the equation alone and its marginal contribution measures the collinear explanatory power of the two components, and is reported in fourth column. Finally, the part of the variance that is not explained by observable individual characteristics and firm dummies is reported in the last column, and is labeled as the contribution of individual factors. It is clear from Table 2 that despite a fairly rich set of information about task complexity and job type, firm dummies are far more important in explaining variation in piece rates than individual and job characteristics. Indeed, unobserved firm heterogeneity is more important than unobserved individual heterogeneity for reward rates, and of similar magnitudes overall for piece rates.

\footnotetext{
${ }^{10}$ Groshen (1991) uses a similar method to document the importance of firm unobserved heterogeneity in explaining intra-industry wage dispersion.
} 


\section{Empirical analysis}

The empirical analysis consists of three parts. We begin by estimating the effect of performance pay on earnings in the presence of both individual and firm unobserved heterogeneity using all the data. Second, we pursue heterogeneity in the effect of performance pay along a potentially important dimension: jobs of different complexity levels. Finally, we address some of the shortcomings of the first set of analyses by exploiting information on the reason for the change in contract: first by using establishment closures, and second by analyzing several 'natural experiments' where a compensation regime change was made in one plant of a firm, but not in another.

\subsection{Linked employer-employee analysis with full data: Econometric issues}

We begin by analyzing the impact of performance pay on earnings using the full data. In particular, our regressions of interest have the general form:

$$
\mathrm{Y}_{\mathrm{i}, \mathrm{t}}=\beta P_{i, t}+X_{i, t} \gamma+Z_{j, t} \pi+\sum_{j=1}^{J} \delta_{j} F_{i t}^{j}+\alpha_{i}+\varepsilon_{i, t}
$$

where $i$ is an index for the individual, $j$ for the firm, and $t$ for the year; the dependent variable is the log of the real hourly wage; the share of hours worked on a performance pay contract (two separate variables: piece rates and reward rates), $P_{i t}$, varies across individuals, firms and time; $X_{i t}$ is a vector of observable employee characteristics and $Z_{j t}$ is observable firm characteristics (which is limited to firm size); $\delta_{j}$ represents the firm effect and $F_{i t}{ }^{j}$ is a dummy that equals one if individual $i$ is employed in firm $j$ at time $t ; \alpha_{i}$ is the individual effect, and finally $\varepsilon_{i t}$ is an error term. Note that we do not have any time invariant covariates in (1). The firm and individual unobserved heterogeneity are correlated with the other covariates and each other. Of course, we still require the assumption that $\varepsilon_{i t}$ is strictly exogenous. This assumption is often referred to as 
'random mobility', and implies that the movement of workers between firms over time is independent of $\varepsilon_{i t}$. Workers' decision to move firms may be a function of the covariates.

Equation (1) can be estimated through three main methods: the least squares dummy variable estimator ('LSDV'), the Abowd, Creecy and Kramarz (2002) direct least squares estimator ('DLS'), and an 'employee-employer-match' fixed effects estimator ('EEMFE'). Abowd, Creecy and Kramarz provide a discussion of these estimators as well as other econometric issues pertaining to linked employee-employer data. We ignore the LSDV and DLS estimators because implementation is problematic, and only useful if one is interested in computing the estimates of $\delta_{j}$ and $\alpha_{i}{ }^{11}$ The latter are unnecessary for our purposes; moreover, their estimation has been subject to some scrutiny (e.g., Andrews, Schank, and Upward 2004). ${ }^{12}$ Subject to the assumptions listed above, the EEMFE estimator yields consistent estimates by taking differences within each unique employee-firm combination, and is thus straightforward to implement. The intuition for this estimator is simply that for each unique employee-employer match $\delta_{j}$ and $\alpha_{i}$ are removed when subtracting means at the level of the match.

Having linked employee-employer panel data is only relevant if people move firms - without such mobility the data is identical to regular panel data. Overall, we have a substantial amount of mobility: as seen in Table 1, of the 91,515 men in the data, 14,778 moved firms at least once.

\footnotetext{
${ }^{11}$ Implementing the LSDV estimator is not straightforward given data such as ours: it is an unbalanced panel since firms and workers can enter and exit the data, and there is no regular pattern between the individual and firm dummies. As a result, it is not possible to use the LSDV estimator on firm-differenced (and individual-differenced) data as in the standard panel data case, but rather a set of firm dummies must be included into the individualdifferenced data. This leads to the computational issue of inverting a $(k+J) \times(k+J)$ matrix where $k$ is the number of covariates. In our data, we were unable to estimate (1) for all 11 years using the LSDV estimator, and were also unable to estimate (1) for even a subset of years when including the 164 occupation dummies. We have a variety of results from the LSDV estimator for other specifications, and the LSDV results are identical to the EEMFE results as should be the case.

${ }^{12}$ As discussed in Andrew, Schank and Upward (2004), another potential problem with computing estimates of the unobserved individual and firm component is sampling error. This is because the unobserved individual effects are 'backed-out' after computing the firm effects (which are just the coefficients on the firm dummies), and thus if the coefficient on a given firm dummy is, for example, overstated the individual effects will be understated and vice versa. The authors argue that this is the reason why virtually all employee-employer studies find a negative relationship between the unobserved individual and firm effects.
} 
The incidence of movement across firms is similar for women. Table 1 also presents summary statistics for the sample of movers. It is important to note that the assumptions made in estimating (1) do not require the movers to be a random sample - what matters is what causes movement. For instance, if movement across firms is driven by the quality of the employeeemployer match (i.e., the matching of $\alpha_{i}$ 's and $\delta_{j}$ 's) then the random mobility assumption likely holds regardless of how the characteristics of movers differ from those of stayers. Similarly, movers with identical characteristics to stayers does not necessarily validate the random mobility assumption. Nevertheless, random mobility will be more convincing if the movers have identical characteristics to the stayers. Table 1 reveals that the movers are very similar to the stayers with respect to individual characteristics; the only systematic difference is firm size. Movers are slightly more likely to be part-time workers, more likely to be on a performance pay contract, and have some minor differences in shift work - but all of these are differences on the order of only 1 to 2.5 percentage points. Average real hourly wages, job complexity, age, industry tenure (and education for 1996 onwards) are virtually identical across the two groups.

\subsection{Linked employer-employee analysis with full data: Results}

Table 3 present the result from (1) estimated by EEMFE as well as a simple OLS regression that does not include controls for unobserved individual or firm-specific heterogeneity. The results from the earnings regressions are suggestive of both strong incentive and selection effects - identical to the previous literature. For piece rates, the simple OLS model yields an estimate of .15 for men - or a $15 \%$ increase in hourly earnings from a change from a fixed rate contract to a $100 \%$ piece rate contract. For reward rates, the OLS estimate is .08. Subject to the fixed effects assumptions discussed above, the incentive effect of piece rates on earnings is about .10. This amounts to $60 \%$ of the OLS estimate implying a selection effect of $40 \%$, a somewhat smaller 
role for selection than generally found in previous studies. The story is the same for reward rates with the .08 coefficient declining to about .06 when estimated by the EEMFE. For women, the results are similar with performance pay estimates of about 1-2 percentage points higher than those found in the male sample. The other estimates from the earnings regressions are consistent with the voluminous literature on wage determination.

What are the productivity gains associated with these earnings premiums? We do not have the data to provide any insights into this question, but in Lazear (2000), a 20\% incentive effect on productivity translates into a 9.6\% hourly wage premium. Based on hourly earnings, our piece rate results are almost identical to Lazear's study of piece rates in a very different setting. It is worth emphasizing that the magnitude of our estimates are somewhat surprising given that the comparison fixed rate contract includes a non-trivial bonus component, which ranges from 2 to $17 \%$ with a mean of $9.5 \%$. The collective agreement for this industry specifies that these bonuses should be based on the supervisor's subjective evaluation of the individual's performance. Given that our estimates are similar to previous studies where the comparison contract was truly a fixed wage rate; our results may imply that subjective, performance-based compensation plans with a fairly small variable-based component have little effect on productivity.

\subsection{Heterogeneity in impacts: Job complexity}

We also investigate whether the incentive effect depends on the complexity level of the individual's job. Economic theories of compensation design tend to focus on monitoring costs piece rates tend not to be used in complex jobs because monitoring output is too difficult (or too costly). Another possibility that has not been thoroughly tested is that it is more difficult for workers to respond to a simple output-based performance measure when their job is complex and involves multiple tasks. To explore the interaction between pay methods and job complexity, we 
estimate our earnings regressions by complexity quartiles. The results are presented in the top panel of Table 4. There does appear to be a strong interaction between performance pay incentive effects and job complexity. The estimated performance pay earnings premiums for piece rates for men fall from the around $11 \%$ in the bottom complexity quartile to $8 \%$ in the middle two quartiles, and then down to $4 \%$ in the top complexity quartile. A very similar decline is seen for reward rates. The trend for women is generally the same as well. It therefore appears that the incentive effect of performance pay declines markedly with job complexity, which supports notions of multi-tasking problems with incentive pay contract design. This strongly suggests that the results from Lazear (2000) - windshield installers - and Shearer (2004) - treeplanters - overstate the productivity gains that a more typical establishment could expected to achieve if implementing performance pay.

\subsection{Evidence from establishment closures}

While the fixed effects estimator allows us to control for unobserved individual-level and establishment-level heterogeneity, strong assumptions are still made. We have discussed the random mobility assumption. Another restrictive assumption is the time-invariant nature of the fixed effects; particularly for $\alpha_{i}$. One criticism of fixed effects methods applied to compensation policy and earnings is that learning processes may change with the contract. Theories of performance pay such as Lazear and Booth and Frank emphasize effort and ability as the inputs to individual production where ability is constant. Parent (2001) discusses an alternative view where effort and skill - which consists of two components, observed skills such as formal training/education and unobserved skills - are the inputs to individual output. If firms (and possibly workers themselves) learn about an individual's (initially) unobserved skills over time 
and change the pay method based on this learning process, the time-invariant assumption of individual-specific unobserved heterogeneity would be violated.

The underlying problem with fixed effects estimators in this context is that we do not observe the reason for the change in compensation scheme. Fortunately, we have several sources of information available to us that allows for some control over the reason for change in contract. First, we know the reason for a job separation, and thus can estimate equation (1) for three subsamples: stayers (workers who stayed in the same firm between time $t$ and $t+1$ ), displaced workers (workers who moved firms because of an establishment closure between time $t$ and $t+1)$, and 'other movers'. For the stayers sub-sample, identification is driven by a change in contracts between time $t$ and $t+1$ within the same firm. For the other samples, the performance pay estimates are identified only by a change in contracts across firms. In particular, the displaced work sample compares individuals whose contract changed following establishment closure with those workers whose contract did not change after moving firms following layoff.

The bottom panel of Table 4 presents the results. The estimates for the stayers sample and 'other changer' samples are similar and consistent with the earlier estimates with piece rate premiums of $9.2 \%$ and $11.9 \%$ respectively for men (10.4 and 13.9\% for women), and reward rate premiums of $4.9 \%$ and $6.4 \%$ respectively for men (6.6 and $8.1 \%$ for women). However, the estimates from the sample of displaced workers are much lower at $7.4 \%$ for piece rates and $3.4 \%$ for reward rates in the male sample (and a statistically insignificant effect for women for reward rates - although the sample size is very small in this case). The displaced worker sample is the one sample where workers likely have much less control over the reason for change in their contract; alternatively stated, the change in contracts for this sub-sample is likely the most exogenous. Arguments in favor of learning or comparative advantage in compensation policy 
(such as Parent, 2001) would likely only apply to stayers and possibly voluntary movers. If the

learning notion is correct, then stayers who change contracts should be the individuals for whom performance pay 'works', and thus should be associated with larger earnings premiums. The learning argument could also hold for voluntary movers if they change from a fixed-rate firm to a piece-rate firm specifically because of this learning process. Overall, there is some evidence that the performance pay incentive effects are lower for individuals who changed contracts for reasons that are more likely to be exogenous to potentially time varying unobserved factors. Nevertheless, the earnings premiums even for the displaced worker sample are substantial, particularly for piece rates.

\subsection{Evidence from a natural experiment}

Our final analysis examines compensation policy regime changes where a given firm made a change in pay method in one plant, but not in another. Unique plant identifiers only became available in 1993 and thus this analysis covers the 1993 to 2000 period. We examined compensation policy over this 8 year period for all firms and plants, and identified five regime changes. Our only sample restriction is that a plant had at least two years in both regimes.

Not surprisingly, when we examine compensation policy by occupation, some job types in the treatment plant (i.e., regime change plant) did not have their pay scheme changed. We focus only on those occupations that did experience a change, and then use the same occupations in the control plant as a comparison group. In almost all cases the occupations in the treatment group affected by the compensation change also exist in the control group. When common occupations does not hold we restrict the sample to those occupations that exist in both the regime change plant and the control plant. Table 5 shows the evolution of compensation policy for these cases where '\% of performance pay' is the fraction of employees in the plant working on a 
performance pay contract. The plant that had its compensation scheme changed is denoted the treatment plant while another plant in the same firm that did not experience a change in compensation policy is denoted the control plant.

Two of these firms (13320 and 16752) had multiple plants that could have been used as the control group; in neither case was there a control plant that was obviously a better control group and so, for brevity, we only present results that pool the control plants. The results are very similar when we separate the control plants. In one case, firm 13572, there are two treatment plants; there are no statistically significant differences pre-regime changes between these two plants and thus we also pool them. Again, the results are virtually unchanged if we examine them separately. One interesting feature of these firms is that we have a mix of different types of performance pay policy changes; some firms adopted piece rates, one adopted reward rates while other abolished performance pay.

Figures 3-7 show average real hourly earnings for each experiment while Table 6 quantifies the impact of the compensation regime change. Below we briefly review the findings in each experiment with particular attention to whether the experimental conditions of common support and common trend hold pre-regime change. Appendix 1 presents summary statistics on the preregime change characteristics for each treatment-control plant combination. We explicitly tested for a common trend in earnings prior to the regime change, which is based on earnings regressions with a treatment dummy, year dummies and interactions between the two over the pre-treatment period only. Common trend holds if the coefficients on the interaction terms are not statistically different from zero. Common support can be seen in Appendix 1, and indicates whether there is a statistically significant difference in pre-treatment period characteristics between the control plant the regime change plant. Overall, while in most cases there are some 
important differences in observable characteristics between the control plant and the treatment plant pre-regime change, the plants are highly similar, and common trend holds in virtually all year-to-year transitions except for Firm 13320.

We begin with the piece rate cases. Firm 13494 is relatively small and only changed the compensation policy of three occupations; the control plant did not make such a change for these same occupations. Common support holds in almost all cases, although the sample size is small. Nevertheless, Appendix 1 reveals a high degree of similarity pre-regime change. The gap in hourly earnings before the change in pay scheme is likely due to the treatment plant being in a rural location which is associated with a large earnings penalty in the industry as a whole. Common trend holds with an almost identical earnings path pre-regime change. As seen in Figure 3, the effect of the regime change was striking. After the treatment plant switched to piece rates, average real hourly earnings increased by $15 \%$ relative to the control plant pre-treatment.

Firm 16752 also adopted piece rates in the treatment plant for a small number of occupations, but only one third of employees within these affected occupations were switched. The control plant is much less comparable than the previous case, being about 4 years older on average and having 2 more years of experience in the industry, as well as being $40 \%$ female (compared to only $5 \%$ in the treatment plant). Nevertheless, common trend holds for two of three years preregime change as seen in Figure 4, and job complexity differed by only a single point. The overall complexity point range for the blue-collar metal industry is 26.5 to 41.1 points. The results reveal an average effect of $8 \%$. It is noteworthy, however, that the $8 \%$ effect may be misleading due to the substantial drop in earnings in 2000 in the treatment plant. Incidentally, in 2000, the incidence of piece rates declined by 10 percentage points. If only one year post regime change is used the estimated effect of the policy change is $11 \%$, a surprising estimate when only 
one third of workers were switched to piece rates. A closer look at the treatment plant reveals that real hourly earnings increased markedly for those treatment plant employees in affected occupations that did not experience a contract change. ${ }^{13}$

Firm 22537 provides an interesting contrast as piece rates were abolished in the treatment plant while the control plant never used piece rates. About $90 \%$ of employees in affected occupations in the treatment plant were switched. While there is a substantial difference in work arrangements (single shifts are twice as likely in the treatment plant) the two plants are highly similar pre-regime change with no statistically significant differences in age, tenure, job complexity, or gender composition (and a minor difference in part-time work), and a common trend in earnings. The effect of the regime change was striking as illustrated in Figure 5. After piece rates were eliminated in the treatment plant, the large gap in earnings diminishes almost entirely with the policy impact estimated at $-7.4 \%$.

Firm 13572 and 13320 are reward rate regime changes. We emphasize here that there is no way of knowing the nature of the reward rate contract - it could be a piece rate labeled as a reward rate or it could consist of no piece rate component at all, but contain a team bonus. In Firm 13572, reward rates were adopted in two different treatment plants while the control plant used reward rates over the entire period. As noted above, we pool the treatment plants. The treatment and control plants are identical in terms of job complexity but there are some sizable differences along other dimensions: in particular, the treatment plant is much older (and experienced) and its employees work exclusively on single shifts (relative to only $21 \%$ of

\footnotetext{
${ }^{13}$ The latter highlights one of the problems with missing the institutional details behind the policy change. It would be interesting to explore why earnings increased among non piece-rate workers in the treatment plant: did the firm pay them more out of fairness considerations, anticipating higher earnings among piece rate workers, or did the fixed rate workers work harder? Other explanations likely exist as well.
} 
employees in single shifts in the control plant). ${ }^{14}$ Nevertheless, there is a common trend in earnings overall the entire pre-regime period. Again, the effect of regime change is striking as illustrated in Figure 6. After performance pay is introduced, real hourly earnings in the treatment plant surpass the earnings levels of the control plant with an overall effect estimated at $10 \%$. The plants in Firm 13320 are the least comparable pre-treatment of all cases. In this case, reward rates were used in both plants, but then abolished in the treatment plant. As seen in Figure 7 very little happened to earnings - in this case the compensation regime change appears to have had no effect.

Overall, the evidence from the regime changes within firms is consistent with our previous results with estimated incentive effects that are somewhat larger than those identified using fixed effects estimators and data on the entire industry.

\section{Conclusions}

There is considerable interest in whether performance-based compensation methods increase productivity. Economic theories of piece rates - where pay is entirely a function of output predict that piece rate workers will earn more than fixed rated workers because of two mechanisms. First, higher ability workers - who have unobserved characteristics such that they would earn more regardless of payment method - select into piece rate contracts (the selection effect), and second, piece rates induce higher levels of effort (the incentive effect). While previous theories have noted the role of the firm in choosing its compensation policy, previous

\footnotetext{
${ }^{14}$ On the surface, Firm 13572 may seem anomalous given that hourly earnings are higher in the control plant despite this plant being substantially younger and less experienced. Of course, one possibility is the reward rate contract indeed, the treatment plant catches up to or surpasses the control plant after performance pay was introduced. The other reason for the earnings differential is likely plant size, which has a strong, positive correlation with hourly earnings. In most cases, the control and treatment plants are of similar size; the firm 13572, the control plant is much larger than the two treatment plants combined.
} 
empirical tests of incentive effects have either ignored establishment characteristics, or focused on a single firm.

This paper estimated the effects of performance pay contracts - both a pure piece rate contract and a quasi piece rate contract - using linked employee-employer panel data from Finland, which is derived from payroll records. This data covers an eleven year period of an entire industry and, in addition to a rich set of individual characteristics including detailed information on job complexity and occupation, allowed us to observe the exact share of hours worked on a given contract in any given year. Finally, the linked employee-employer nature of the data allows us to control for both individual and establishment unobserved heterogeneity.

We find that piece rate workers earn 9-10\% more than fixed rate workers and reward rate (quasi-piece rate) workers earn 6-7\% more than fixed rate workers, with women earning a performance pay premium of one percentage point higher than men for both contracts. These estimates are about $60 \%$ the magnitude of simple OLS estimates that control only for observable characteristics. The incentive effect declines markedly with job complexity, from $11 \%$ in the lowest complexity quartile to $4 \%$ in the highest complexity quartile. Estimates from displaced workers, where identification is driven by comparing workers who changed contracts following an establishment closure with workers who did not change contracts after displacement, reveal incentive effects about two percentage points lower. We also exploit several natural experiments where a firm made a mass change in compensation policy within one plant, but not in another. In all cases but one the treatment and control plants had a common trend in earnings before the regime cases, and overall the plants are highly similar with respect to observable characteristics pre-regime change. The results from these experiments are consistent with the rest of the analysis, with estimated policy impacts somewhat larger than those obtained in the full sample. 


\section{References}

Abowd, John, Robert Creecy, and Francis Kramarz. 2002. "Computing person and firm effects using linked longitudinal employer-employee data.” Technical paper 2002-06, U.S. Census Bureau.

Bandiera, Oriana, Iwan Barankay and Imran Rasul. 2005. "Social preferences and the response to incentives: Evidence from personnel data.” Forthcoming Quarterly Journal of Economics

Banker, Rajiv, Seok-Young Lee and Gorden Potter. 1996. "A field study of the impact of a performance-based incentive plan.” Journal of Accounting and Economics, Volume 21, Number 2, pages 195-226.

Booth, Alison L. and Jeff Frank. 1999. “Earnings, productivity, and performance-related pay.” Journal of Labor Economics, Volume 17, Number 3, pages 447-463.

Brown, Charles. 1990. “Firms' choice of method of pay.” Industrial and Labor Relations Review, Volume 43, Number 3, pages s165-183.

Brown, Charles. 1992. "Wage levels and methods of pay.” Rand Journal of Economics, Volume 23, Number 3, pages 366-375.

Ehrenberg, Ronald E. 1990 “Introduction: Do compensation policies matter?” Industrial and Labor Relations Review, Volume 43, Number 3, pages s3-10.

Gibbons, Robert and Michael Waldman. 1999. "Careers in organizations: Theory and evidence.” In Orley Ashenfelter and David Card (editors): Handbook of Labor Economics, volume 3.

Groshen, Erica. 1991. "Sources of intra-industry wage dispersion: How much do employers matter?” Quarterly Journal of Economics, Volume 106, Number 3, pages 869-884.

Lazear, Edward P. 1986. “Salaries and piece rates.” Journal of Business, Volume 59, Number 3, pages $405-431$.

Lazear, Edward P. 2000. "Performance pay and productivity.” American Economic Review, Volume 90, Number 5, pages 1346-1361.

Parent, Daniel. 1999. "Methods of pay and earnings: A longitudinal analysis.” Industrial and Labor Relations Review, Volume 53, Number 1, pages 71-86.

Parent, Daniel. 2001. “The effect of pay-for-performance contracts on wages.” CIRANO Working Paper \#2001s-05.

Prendergast, Canice. 1999. “The provision of incentive in firms.” Journal of Economic Literature, Volume 37, Number 1, pages 7-63. 
Seiler, Eric. 1984. "Piece rate vs. time rate: The effect of incentives on earnings." Review of Economics and Statistics, Volume 66, Number 3, pages 363-376.

Shearer, Bruce. 2004. "Piece rates, fixed rates, and incentives: Evidence from a field experiment.” Review of Economic Studies, Volume 71, Number 247, pages 513-534. 


\section{Figure 1}

Kernel estimate of the distribution of the piece rate share of hours among workers who work positive number of piece rate hours: Men, 1990-2000

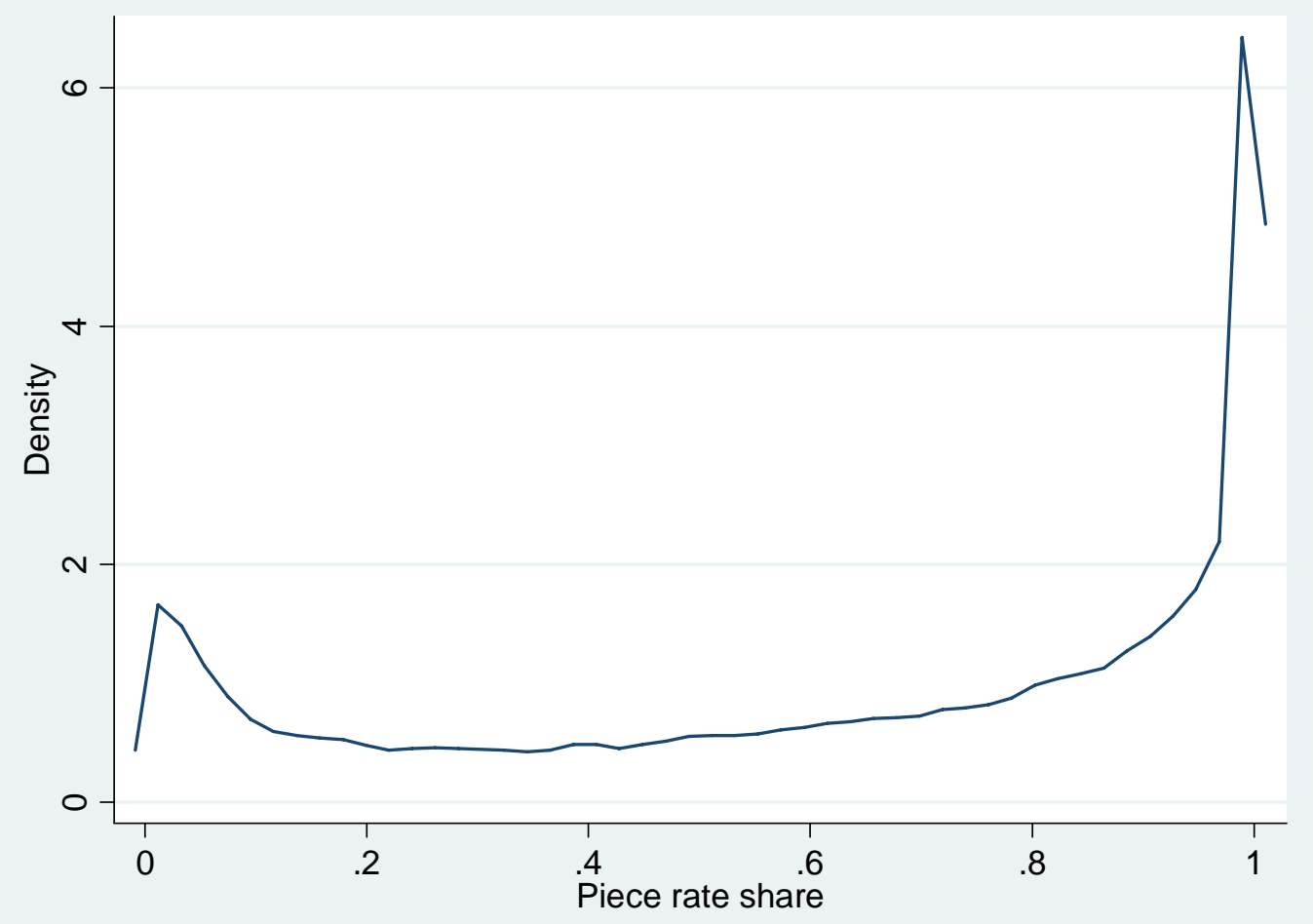




\section{Figure 2}

Kernel estimate of the distribution of the reward rate share of hours among workers who work positive number of reward rate hours: Men, 1990-2000

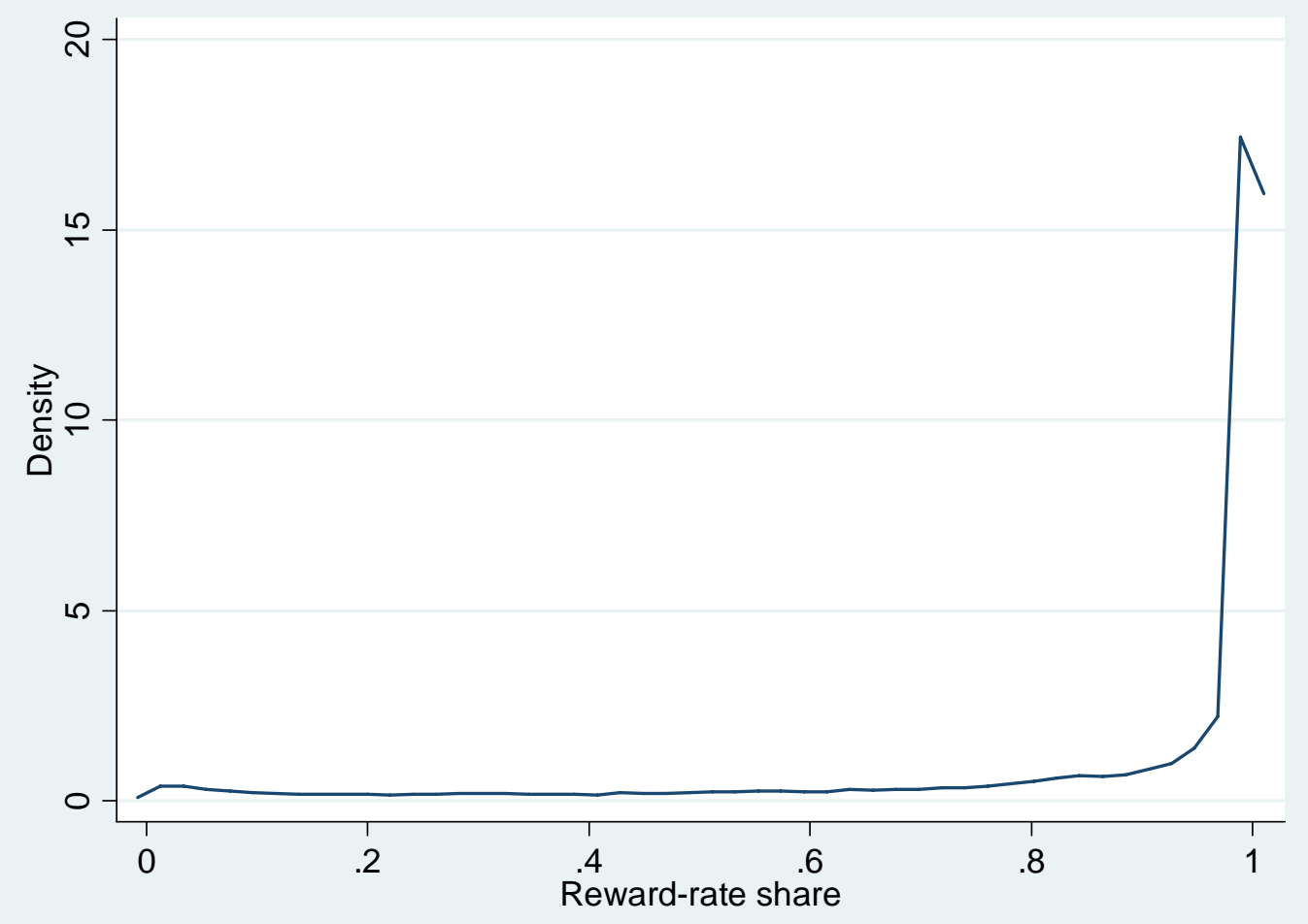


Figure 3: Average real hourly earnings in Firm 13494

(Treatment plant adopted piece rates in 1996 - Control plant used fixed rates)

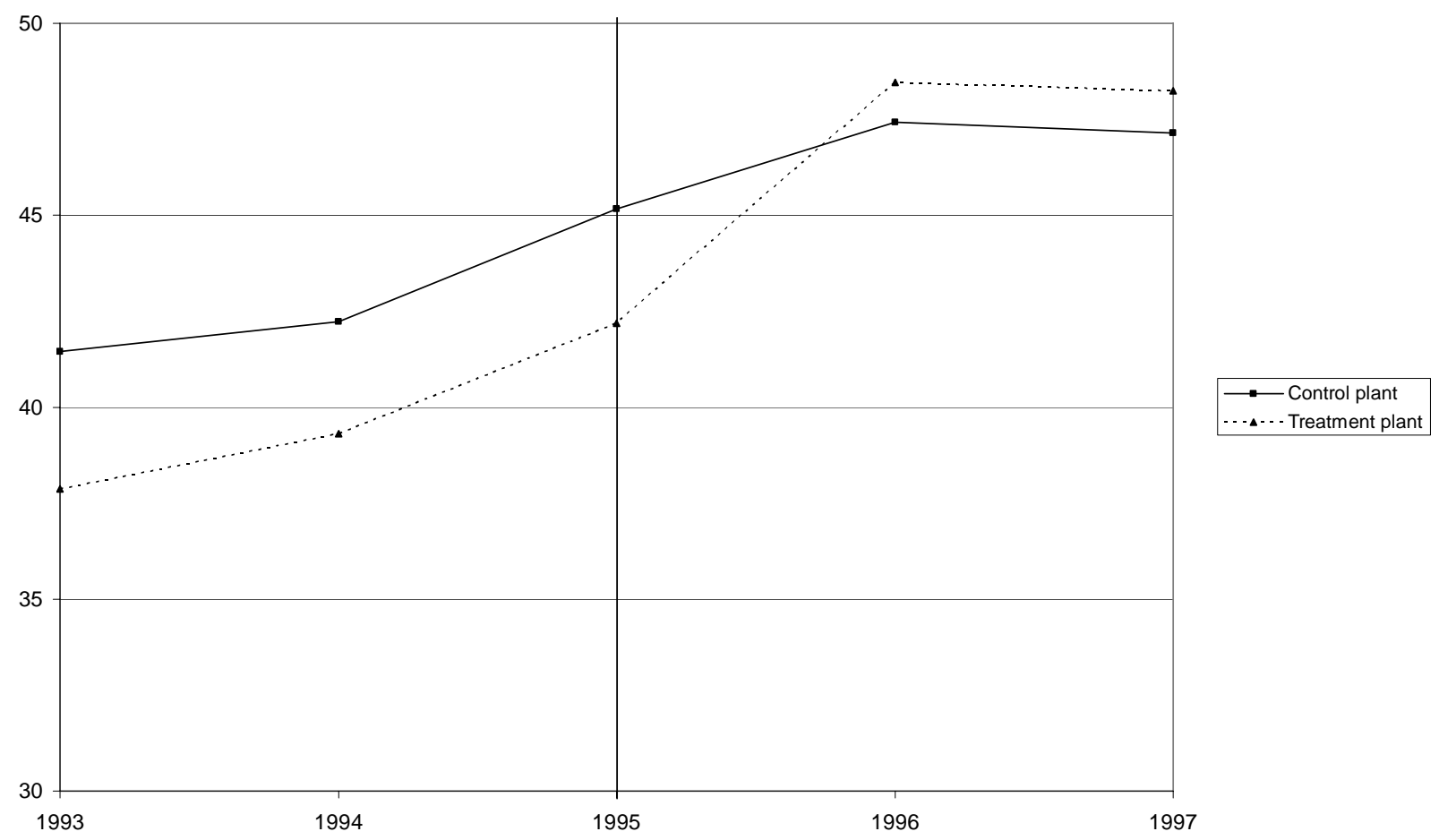


Figure 4: Average real hourly earnings in Firm 16752

(Treatment plant adopted piece rates in 1997 - Control plant used fixed rates)

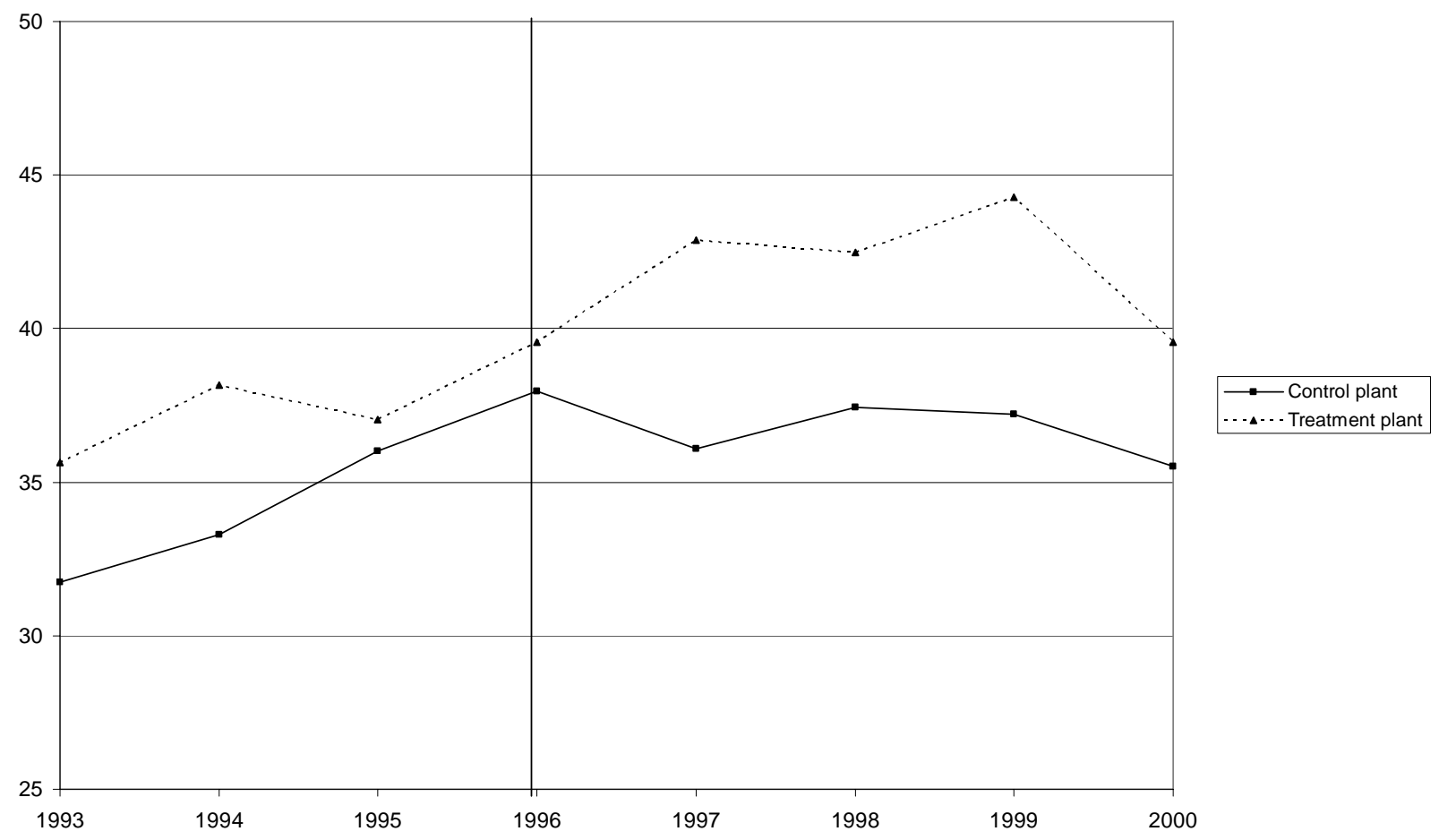


Figure 5: Average real hourly earnings for Firm 22537 (Treatment plant eliminated piece rates in 1995 - Control plant on fixed rates)

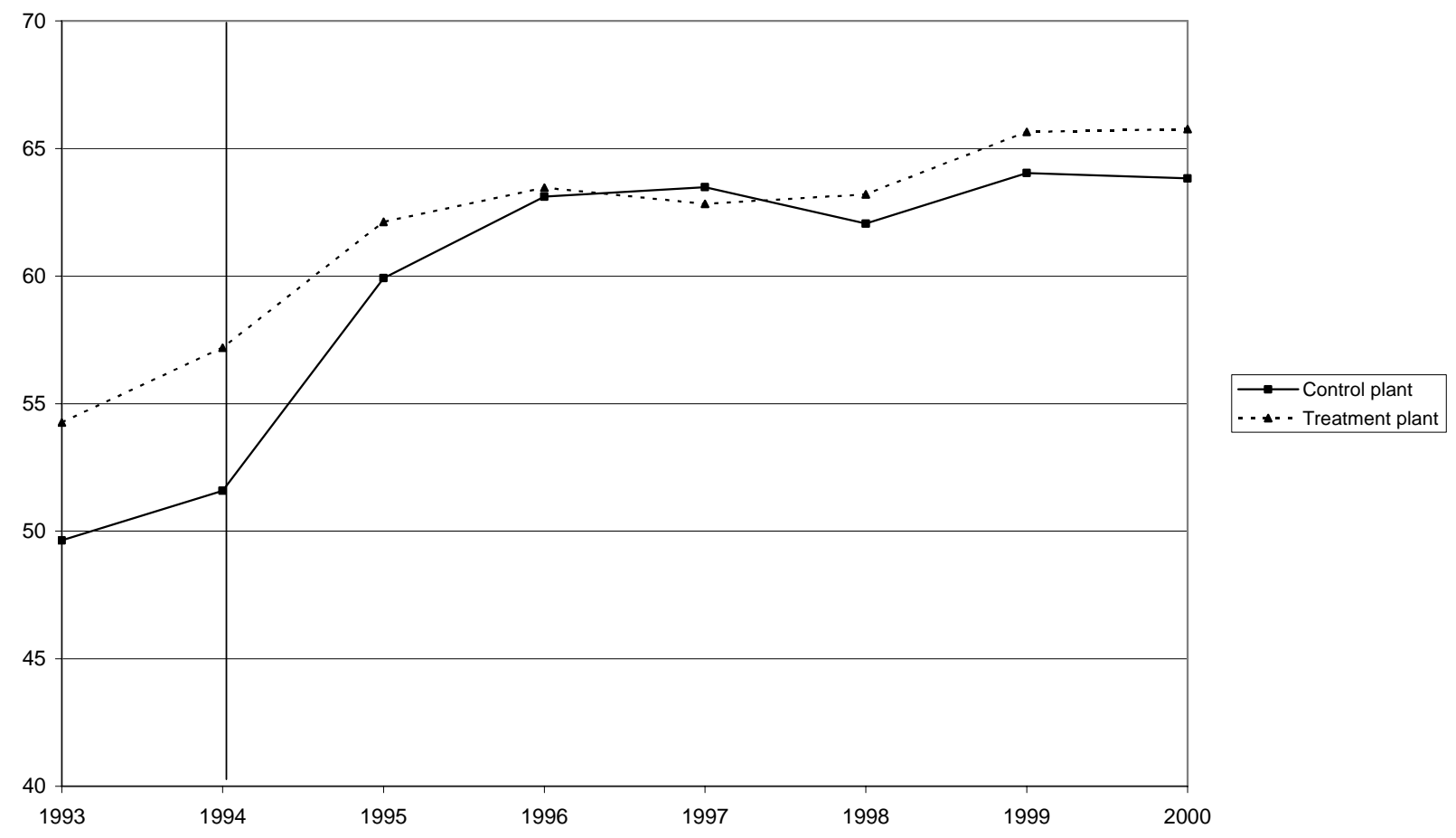


Figure 6: Average real hourly earnings for Firm 13572

(Treatment plant adopted reward rates in 1998 - Control plant used reward rates)

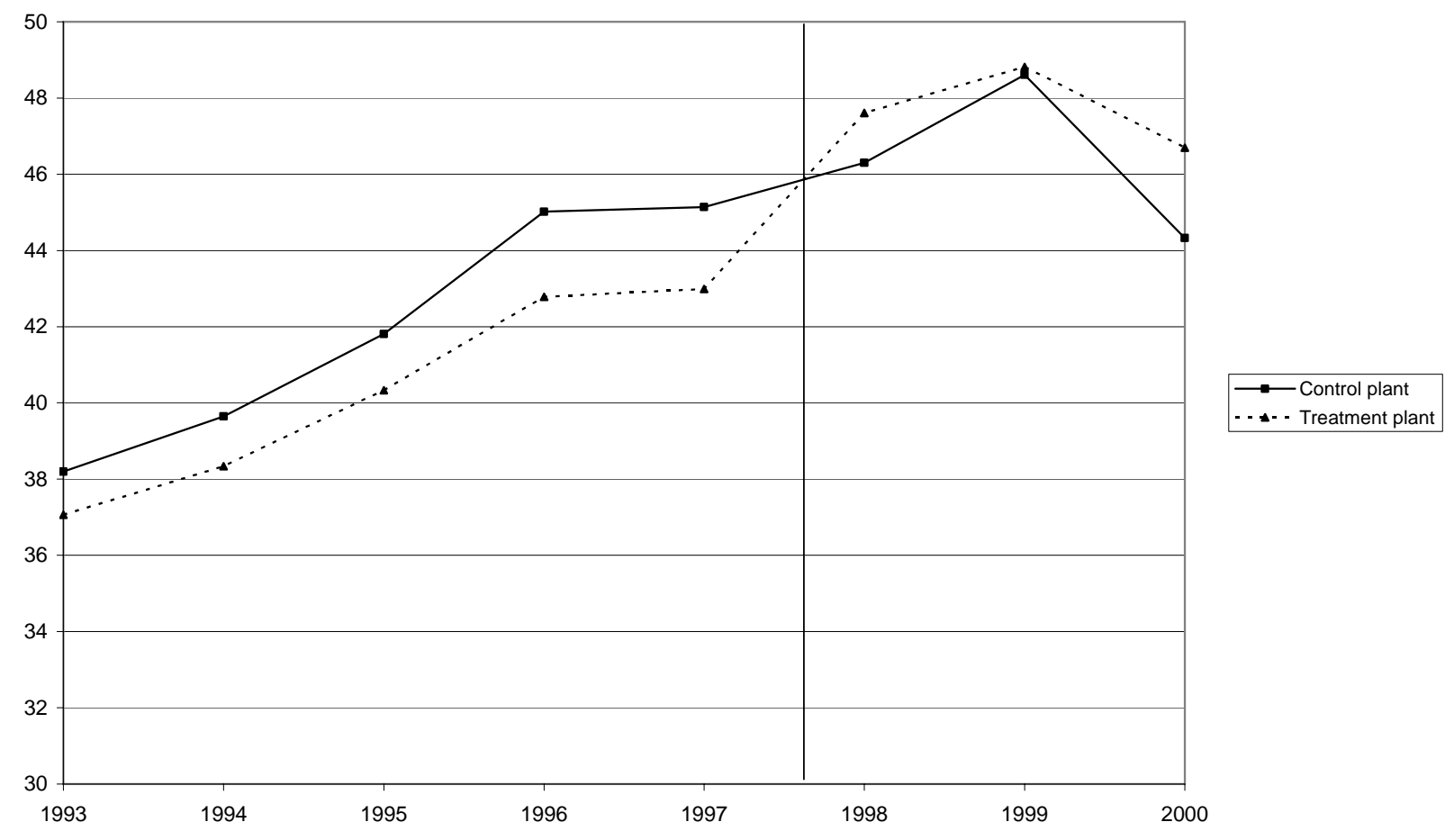


Figure 7: Average real hourly earnings in Firm 13320

(Treatment plant eliminated reward rates in 1997 - Control plant used fixed rates)

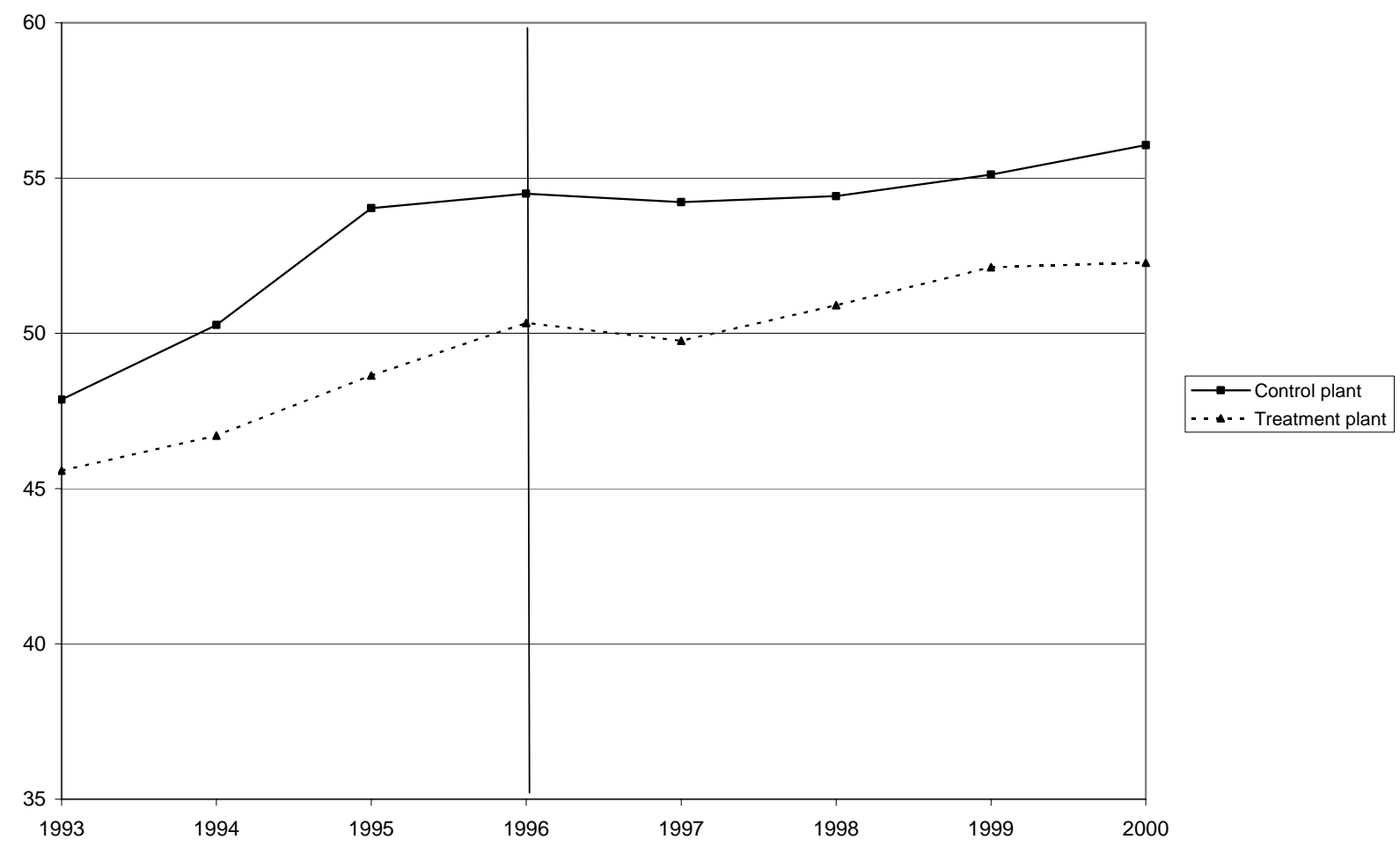


Table 1

Summary statistics

\begin{tabular}{|c|c|c|c|c|}
\hline \multirow[t]{2}{*}{ Variable } & \multicolumn{2}{|c|}{ Men } & \multicolumn{2}{|c|}{ Women } \\
\hline & Full sample & Movers & Full sample & Movers \\
\hline Average real hourly wage & $\begin{array}{l}49.11 \\
(.012)\end{array}$ & $\begin{array}{l}50.15 \\
(.044)\end{array}$ & $\begin{array}{l}40.95 \\
(.018)\end{array}$ & $\begin{array}{l}40.52 \\
(.060)\end{array}$ \\
\hline Fixed rate hourly wage* & $\begin{array}{l}47.45 \\
(.017) \\
\end{array}$ & $\begin{array}{l}48.06 \\
(.064) \\
\end{array}$ & $\begin{array}{l}39.00 \\
(.021) \\
\end{array}$ & $\begin{array}{l}38.37 \\
(.083) \\
\end{array}$ \\
\hline Reward rate hourly wage* & $\begin{array}{l}51.42 \\
(.050)\end{array}$ & $\begin{array}{l}53.07 \\
(.108)\end{array}$ & $\begin{array}{l}42.96 \\
(.028)\end{array}$ & $\begin{array}{l}43.03 \\
(.110)\end{array}$ \\
\hline Piece rate hourly wage* & $\begin{array}{l}55.20 \\
(.071) \\
\end{array}$ & $\begin{array}{l}56.19 \\
(.220) \\
\end{array}$ & $\begin{array}{l}42.75 \\
(.050) \\
\end{array}$ & $\begin{array}{l}41.63 \\
(.158) \\
\end{array}$ \\
\hline Age & $\begin{array}{l}38.20 \\
(.015)\end{array}$ & $\begin{array}{l}38.69 \\
(.052)\end{array}$ & $\begin{array}{l}40.13 \\
(.030) \\
\end{array}$ & $\begin{array}{l}40.42 \\
(.105)\end{array}$ \\
\hline $\begin{array}{l}\text { Years of experience in } \\
\text { industry }\end{array}$ & $\begin{array}{l}12.45 \\
(.015) \\
\end{array}$ & $\begin{array}{l}13.06 \\
(.052) \\
\end{array}$ & $\begin{array}{l}10.27 \\
(.023) \\
\end{array}$ & $\begin{array}{l}11.32 \\
(.089) \\
\end{array}$ \\
\hline $\begin{array}{l}\text { \% of hours worked on piece } \\
\text { rate contract }\end{array}$ & $\begin{array}{l}.104 \\
(.000)\end{array}$ & $\begin{array}{l}.130 \\
(.002)\end{array}$ & $\begin{array}{l}.120 \\
(.001) \\
\end{array}$ & $\begin{array}{l}.152 \\
(.003) \\
\end{array}$ \\
\hline $\begin{array}{l}\text { \% of hours worked on reward } \\
\text { rate contract }\end{array}$ & $\begin{array}{l}.347 \\
(.001)\end{array}$ & $\begin{array}{c}.391 \\
(.002)\end{array}$ & $\begin{array}{l}.357 \\
(.001)\end{array}$ & $\begin{array}{l}.347 \\
(.005)\end{array}$ \\
\hline Job complexity & $\begin{array}{l}35.39 \\
(.005)\end{array}$ & $\begin{array}{l}35.96 \\
(.016)\end{array}$ & $\begin{array}{l}30.91 \\
(.007)\end{array}$ & $\begin{array}{l}30.87 \\
(.030)\end{array}$ \\
\hline Single shift & $\begin{array}{l}.618 \\
(.001)\end{array}$ & $\begin{array}{c}.604 \\
(.003)\end{array}$ & $\begin{array}{l}.575 \\
(.001)\end{array}$ & $\begin{array}{l}.574 \\
(.005)\end{array}$ \\
\hline Double shift & $\begin{array}{c}.212 \\
(.001)\end{array}$ & $\begin{array}{l}.252 \\
(.002)\end{array}$ & $\begin{array}{l}.233 \\
(.001)\end{array}$ & $\begin{array}{l}.263 \\
(.005) \\
\end{array}$ \\
\hline Triple shift & $\begin{array}{l}.170 \\
(.001)\end{array}$ & $\begin{array}{c}.144 \\
(.002)\end{array}$ & $\begin{array}{l}.192 \\
(.001)\end{array}$ & $\begin{array}{l}.164 \\
(.004)\end{array}$ \\
\hline Firm size & $\begin{array}{l}982.81 \\
(1.88)\end{array}$ & $\begin{array}{l}721.96 \\
(4.62)\end{array}$ & $\begin{array}{l}789.31 \\
(2.71)\end{array}$ & $\begin{array}{l}652.44 \\
(7.09)\end{array}$ \\
\hline Part-time & $\begin{array}{c}.039 \\
(.000)\end{array}$ & $\begin{array}{c}.034 \\
(.001)\end{array}$ & $\begin{array}{l}.047 \\
(.001)\end{array}$ & $\begin{array}{c}.046 \\
(.002)\end{array}$ \\
\hline Number of observations & 470586 & 35710 & 131226 & 9315 \\
\hline Number of individuals & 91515 & 14778 & 28667 & 4020 \\
\hline
\end{tabular}

NOTES: Standard errors are in parentheses. Movers are the subset of the full sample who moved firms (at least once). The * indicates that the variable is only defined for a subset of the full sample. 
Table 2

Analysis of variance of performance pay: Men, 1990-2000

\begin{tabular}{|c|c|c|c|c|c|}
\hline Year & $\begin{array}{c}\text { Individual + } \\
\text { task }\end{array}$ & $\begin{array}{c}\text { Firm } \\
\text { dummies }\end{array}$ & $\begin{array}{c}\text { Joint } \\
\text { individual + } \\
\text { task and } \\
\text { firm } \\
\text { dummies } \\
\end{array}$ & $\begin{array}{c}\text { Between } \\
\text { individual + } \\
\text { task and } \\
\text { firm } \\
\text { dummies } \\
\end{array}$ & Individual \\
\hline & \multicolumn{5}{|c|}{ Piece Rates } \\
\hline 1990 & .077 & .275 & .100 & .452 & .548 \\
\hline 1991 & .066 & .289 & .107 & .462 & .538 \\
\hline 1992 & .053 & .331 & .123 & .507 & .493 \\
\hline 1993 & .060 & .334 & .119 & .514 & .486 \\
\hline 1994 & .050 & .351 & .141 & .543 & .457 \\
\hline 1995 & .048 & .362 & .159 & .568 & .432 \\
\hline 1996 & .039 & .373 & .137 & .549 & .451 \\
\hline 1997 & .028 & .403 & .122 & .553 & .447 \\
\hline 1998 & .030 & .426 & .123 & .579 & .421 \\
\hline 1999 & .029 & .416 & .162 & .608 & .392 \\
\hline \multirow[t]{2}{*}{2000} & .034 & .381 & .155 & .570 & .430 \\
\hline & \multicolumn{5}{|c|}{ Reward Rates } \\
\hline 1990 & .067 & .324 & .120 & .511 & .489 \\
\hline 1991 & .057 & .359 & .144 & .559 & .441 \\
\hline 1992 & .055 & .401 & .154 & .610 & .390 \\
\hline 1993 & .049 & .371 & .194 & .614 & .386 \\
\hline 1994 & .048 & .433 & .171 & .652 & .348 \\
\hline 1995 & .041 & .455 & .217 & .714 & .286 \\
\hline 1996 & .043 & .436 & .222 & .701 & .299 \\
\hline 1997 & .036 & .470 & .219 & .725 & .275 \\
\hline 1998 & .034 & .520 & .198 & .751 & .249 \\
\hline 1999 & .032 & .514 & .206 & .752 & .248 \\
\hline 2000 & .032 & .501 & .230 & .763 & .237 \\
\hline
\end{tabular}

NOTES: The dependent variable is the share of hours worked on piece rates, and share of hours worked on reward rates. Second column reports the difference between the $\mathrm{R}^{2}$ of a model where individual + task characteristics + occupation dummies and firm dummies are introduced together and the $\mathrm{R}^{2}$ of a model where only firm dummies are introduced. Similarly the third column reports the difference of $\mathrm{R}^{2}$ a model where individual + task characteristics + occupation dummies and firm dummies are introduced together and the $\mathrm{R}^{2}$ of a model where only individual + task characteristics and occupation dummies are introduced. The fourth column reports the difference between the marginal contribution and $\mathrm{R}^{2}$ of a model where the component is introduced alone. The fifth column reports the $\mathrm{R}^{2}$ of the model where individual + task characteristics are introduced together and the sixth column reports the residual variation. 
Table 3

Estimated coefficients for earnings regressions

\begin{tabular}{|c|c|c|c|c|}
\hline \multirow[t]{2}{*}{ Variable } & \multicolumn{2}{|c|}{ Men } & \multicolumn{2}{|c|}{ Women } \\
\hline & OLS & EEMFE & OLS & EEMFE \\
\hline Piece rate share & $\begin{array}{l}.147 * * * \\
(.012)\end{array}$ & $\begin{array}{c}.089 * * * \\
(.001)\end{array}$ & $\begin{array}{c}.160 * * * \\
(.012)\end{array}$ & $\begin{array}{c}.103 * * * \\
(.001)\end{array}$ \\
\hline Reward-rate share & $\begin{array}{l}.079 * * * \\
(.009)\end{array}$ & $\begin{array}{c}.053^{* * *} \\
(.000) \\
\end{array}$ & $\begin{array}{c}.090 * * * \\
(.009) \\
\end{array}$ & $\begin{array}{c}.069 * * * \\
(.001)\end{array}$ \\
\hline Age & $\begin{array}{c}0.090^{* * *} \\
(.007)\end{array}$ & & $\begin{array}{c}.035^{* * *} \\
(.006)\end{array}$ & \\
\hline Age squared & $\begin{array}{c}-0.010 * * * \\
(.001) \\
\end{array}$ & $\begin{array}{c}-0.016 * * * \\
(.000) \\
\end{array}$ & $\begin{array}{c}-.004^{* * *} \\
(.001) \\
\end{array}$ & $\begin{array}{c}-.009 * * * \\
(.000)\end{array}$ \\
\hline Industry tenure & $\begin{array}{c}0.042^{* * *} \\
(.004)\end{array}$ & & $\begin{array}{c}.055^{* * *} \\
(.005)\end{array}$ & \\
\hline $\begin{array}{l}\text { Industry tenure } \\
\text { squared }\end{array}$ & $\begin{array}{c}-0.008 * * * \\
(.001)\end{array}$ & $\begin{array}{c}-0.004^{* * *} \\
(.000)\end{array}$ & $\begin{array}{c}-.011^{* * * *} \\
(.002)\end{array}$ & $\begin{array}{c}-.012 * * * \\
(.001)\end{array}$ \\
\hline $\begin{array}{l}\text { Log of job } \\
\text { complexity }\end{array}$ & $\begin{array}{l}.723 * * * \\
(.031) \\
\end{array}$ & $\begin{array}{c}.466^{* * *} \\
(.003) \\
\end{array}$ & $\begin{array}{c}.772 * * * \\
(.033) \\
\end{array}$ & $\begin{array}{c}.535 * * * \\
(.005) \\
\end{array}$ \\
\hline Double shift & $\begin{array}{c}.004 \\
(.005) \\
\end{array}$ & $\begin{array}{c}.006 * * * \\
(.000)\end{array}$ & $\begin{array}{c}-.014 * * \\
(.005)\end{array}$ & $\begin{array}{c}.000 \\
(.001) \\
\end{array}$ \\
\hline Triple shift & $\begin{array}{l}-.013^{*} \\
(.007)\end{array}$ & $\begin{array}{c}.009 * * * \\
(.001)\end{array}$ & $\begin{array}{c}-.018 * * \\
(.008)\end{array}$ & $\begin{array}{l}-.001 \\
(.001)\end{array}$ \\
\hline Part-time dummy & $\begin{array}{c}.005 \\
(.005) \\
\end{array}$ & $\begin{array}{c}.009 * * * \\
(.001) \\
\end{array}$ & $\begin{array}{l}-.001 \\
(.005) \\
\end{array}$ & $\begin{array}{c}-.008 * * * \\
(.001)\end{array}$ \\
\hline $\begin{array}{l}\text { Firm size } \\
(* 100)\end{array}$ & $\begin{array}{l}.001^{* * *} \\
(.000)\end{array}$ & $\begin{array}{c}-.001^{* * * *} \\
(.000)\end{array}$ & $\begin{array}{c}.002 * * * \\
(.000)\end{array}$ & $\begin{array}{c}.001 * * * \\
(.000)\end{array}$ \\
\hline Constant & $\begin{array}{c}.885^{* * *} \\
(.110) \\
\end{array}$ & $\begin{array}{c}2.33^{* * *} \\
(.028)\end{array}$ & $\begin{array}{c}1.001^{* * *} \\
(.106)\end{array}$ & $\begin{array}{c}1.89 * * * \\
(.057)\end{array}$ \\
\hline R squared & .63 & .66 & .65 & .68 \\
\hline
\end{tabular}

NOTES: Dependent variable is the log of real hourly earnings. Robust standard errors are in parentheses, and for OLS, are adjusted for clustering at the firm level. Statistical significance is denoted by *** for the $1 \%$ level, ** for the $5 \%$ level, and $*$ for the $10 \%$ level. The number of observations is 470,586 for men and 131,226 for women. The number of firms is 602; the number of individuals is 91,515 and 28,667 for men and women respectively; and the number of employee-employer matched dummies for the EEMFE estimator is 113,909 for men and 34,772 for women. All regressions include 10 year dummies and 165 occupational dummies. 
Table 4

Estimated coefficients for alternative specifications

\begin{tabular}{|c|c|c|c|c|}
\hline \multirow[t]{2}{*}{ Specification } & \multicolumn{2}{|c|}{ Men } & \multicolumn{2}{|c|}{ Women } \\
\hline & $\begin{array}{l}\text { Piece rate } \\
\text { coefficient }\end{array}$ & $\begin{array}{c}\text { Reward rate } \\
\text { coefficient }\end{array}$ & $\begin{array}{l}\text { Piece rate } \\
\text { coefficient }\end{array}$ & $\begin{array}{c}\text { Reward rate } \\
\text { coefficient }\end{array}$ \\
\hline \multicolumn{5}{|c|}{ By complexity quartiles } \\
\hline $\begin{array}{l}\text { Complexity quartile } \\
1\end{array}$ & $\begin{array}{c}.111 \\
(.002) \\
\end{array}$ & $\begin{array}{c}.069 \\
(.001) \\
\end{array}$ & $\begin{array}{c}.105 \\
(.001) \\
\end{array}$ & $\begin{array}{c}.072 \\
(.001) \\
\end{array}$ \\
\hline $\begin{array}{l}\text { Complexity quartile } \\
2\end{array}$ & $\begin{array}{c}.085 \\
(.001) \\
\end{array}$ & $\begin{array}{c}.048 \\
(.001) \\
\end{array}$ & $\begin{array}{c}.100 \\
(.004) \\
\end{array}$ & $\begin{array}{c}.052 \\
(.002) \\
\end{array}$ \\
\hline $\begin{array}{l}\text { Complexity quartile } \\
3\end{array}$ & $\begin{array}{c}.083 \\
(.001) \\
\end{array}$ & $\begin{array}{c}.046 \\
(.001) \\
\end{array}$ & $\begin{array}{c}.089 \\
(.008) \\
\end{array}$ & $\begin{array}{c}.051 \\
(.003) \\
\end{array}$ \\
\hline $\begin{array}{l}\text { Complexity quartile } \\
4\end{array}$ & $\begin{array}{c}.042 \\
(.002) \\
\end{array}$ & $\begin{array}{c}.032 \\
(.001) \\
\end{array}$ & $\begin{array}{l}.025 * \\
(.015) \\
\end{array}$ & $\begin{array}{c}.044 \\
(.006) \\
\end{array}$ \\
\hline \multicolumn{5}{|c|}{ By mobility category } \\
\hline Stayers & $\begin{array}{c}.092 \\
(.001) \\
\end{array}$ & $\begin{array}{c}.049 \\
(.001) \\
\end{array}$ & $\begin{array}{c}.104 \\
(.001) \\
\end{array}$ & $\begin{array}{c}.066 \\
(.001) \\
\end{array}$ \\
\hline Displaced workers & $\begin{array}{c}.074 \\
(.011) \\
\end{array}$ & $\begin{array}{c}.034 \\
(.009) \\
\end{array}$ & $\begin{array}{c}.071 \\
(.018) \\
\end{array}$ & $\begin{array}{l}.037^{*} \\
(.017) \\
\end{array}$ \\
\hline Other movers & $\begin{array}{l}.119 \\
(.011)\end{array}$ & $\begin{array}{c}.064 \\
(.008)\end{array}$ & $\begin{array}{c}.139 \\
(.019) \\
\end{array}$ & $\begin{array}{c}.081 \\
(.014) \\
\end{array}$ \\
\hline
\end{tabular}

NOTES: All regressions in the top panel are estimated by EEMFE; all regressions in the bottom panel are estimated by standard first-differences. The dependent variable is the log of real hourly earnings. Robust standard errors are in parentheses. All estimated coefficients except * are statistically significant at the $1 \%$ level. All regressions include controls for age (and its square), industry tenure (and its square), job complexity, shift-work, part-time work, firm size, year dummies, and occupation dummies. 
Table 5

Compensation regime changes within firms

\begin{tabular}{|c|c|c|c|c|c|c|c|c|}
\hline & 1993 & 1994 & 1995 & 1996 & 1997 & 1998 & 1999 & 2000 \\
\hline & \multicolumn{8}{|c|}{ Firm 13494 - Fixed rate to piece rate change } \\
\hline \multicolumn{9}{|l|}{ Treatment } \\
\hline$\%$ on piece & 0 & 0 & 0 & 1 & 1 & - & - & - \\
\hline \multicolumn{9}{|l|}{ Control } \\
\hline$\%$ on piece & 0 & 0 & 0 & 0 & 0 & - & - & - \\
\hline & \multicolumn{8}{|c|}{ Firm 16752 - Fixed rate to piece rate change } \\
\hline Treatment & & & & & & & & \\
\hline \multicolumn{9}{|l|}{ Control } \\
\hline$\%$ on piece & 0 & 0 & 0 & 0 & 0 & 0 & 0 & 0 \\
\hline & \multicolumn{8}{|c|}{ Firm 22537 - Piece rate to fixed rate change } \\
\hline \multicolumn{9}{|l|}{ Treatment } \\
\hline$\%$ on piece & .90 & .91 & 0 & 0 & 0 & 0 & 0 & 0 \\
\hline \multicolumn{9}{|l|}{ Control } \\
\hline$\%$ on piece & 0 & 0 & 0 & 0 & 0 & 0 & 0 & 0 \\
\hline Treatment & & & & & & & & \\
\hline$\%$ on reward & 0 & 0 & 0 & 0 & 0 & 1 & 1 & 1 \\
\hline \multicolumn{9}{|l|}{ Control } \\
\hline$\%$ on reward & 1 & 1 & 1 & 1 & 1 & 1 & 1 & 1 \\
\hline & \multicolumn{8}{|c|}{ Firm 13320 - Reward rate to fixed rate change } \\
\hline Treatment & & & & & & & & \\
\hline$\%$ on reward & .75 & .79 & 1 & 0 & 0 & 0 & 0 & 0 \\
\hline \multicolumn{9}{|l|}{ Control } \\
\hline \% on reward & 1 & 1 & 1 & 1 & 1 & 1 & 1 & 1 \\
\hline
\end{tabular}




\section{Table 6}

\section{Estimated coefficients from natural experiments}

\begin{tabular}{|l|c|c|c|c|c|}
\hline Variable & Firm 13494 & Firm 16752 & Firm 22537 & Firm 13572 & Firm 13320 \\
\hline & $\begin{array}{c}\text { Fixed to } \\
\text { piece }\end{array}$ & $\begin{array}{c}\text { Fixed to } \\
\text { piece }\end{array}$ & $\begin{array}{c}\text { Piece to } \\
\text { fixed }\end{array}$ & $\begin{array}{c}\text { Fixed to } \\
\text { reward }\end{array}$ & $\begin{array}{c}\text { Reward to } \\
\text { fixed }\end{array}$ \\
\hline Treatment plant & $\begin{array}{c}.145^{* * *} \\
(.026)\end{array}$ & $\begin{array}{c}.054 \\
(.037)\end{array}$ & $\begin{array}{c}.093^{* * *} \\
(.008)\end{array}$ & $\begin{array}{c}-.058^{* * *} \\
(.004)\end{array}$ & $\begin{array}{c}-.083^{* * *} \\
(.007)\end{array}$ \\
\hline Treatment period & $.038^{*}$ & .003 & $.212^{* * *}$ & $.060^{* * *}$ & $.074^{* * *}$ \\
& $(.022)$ & $(.033)$ & $(.007)$ & $(.003)$ & $(.003)$ \\
\hline Treatment plant * Treatment & $.152^{* * *}$ & $.083^{* *}$ & $-.074^{* * *}$ & $.112^{* * *}$ & $.015^{*}$ \\
period & $(.037)$ & $(.040)$ & $(.009)$ & $(.006)$ & $(.008)$ \\
\hline Number of observations & 138 & 310 & 3541 & 5932 & 1424 \\
\hline
\end{tabular}

NOTES: All regressions are estimated by OLS. The dependent variable is the log of real hourly earnings. Robust standard errors are in parentheses. Statistical significance is denoted by $* * *$ for the $1 \%$ level, $* *$ for the $5 \%$ level, and * for the $10 \%$ level. 
Appendix 1

Descriptive statistics for regime changes

\begin{tabular}{|c|c|c|}
\hline \multirow[t]{2}{*}{ Pre-regime change characteristic } & \multicolumn{2}{|c|}{ Firm 13494} \\
\hline & Control plant & Treatment plant \\
\hline Age & $\begin{array}{l}46.46 \\
(1.32)\end{array}$ & $\begin{array}{l}44.41 \\
(1.42)\end{array}$ \\
\hline Job complexity & $\begin{array}{l}34.83 \\
(.498)\end{array}$ & $\begin{array}{l}34.63 \\
(.688)\end{array}$ \\
\hline Job tenure & $\begin{array}{c}17.19 \\
(1.40)\end{array}$ & $\begin{array}{l}14.50 \\
(1.34)\end{array}$ \\
\hline Female & 0 & 0 \\
\hline Part-time & $\begin{array}{c}.017 \\
(.017)\end{array}$ & 0 \\
\hline \multirow[t]{3}{*}{ Single shift } & $\begin{array}{c}.931 \\
(.034)\end{array}$ & $\begin{array}{l}.727 * \\
(.097) \\
\end{array}$ \\
\hline & \multicolumn{2}{|c|}{ Firm 16752} \\
\hline & Control plant & Treatment plant \\
\hline Age & $\begin{array}{l}31.67 \\
(.321)\end{array}$ & $\begin{array}{c}27.63^{*} \\
(.940)\end{array}$ \\
\hline Job complexity & $\begin{array}{l}31.02 \\
(.239) \\
\end{array}$ & $\begin{array}{c}32.29 * \\
(.367) \\
\end{array}$ \\
\hline Industry tenure & $\begin{array}{c}5.33 \\
(.896)\end{array}$ & $\begin{array}{l}2.15^{*} \\
(.283)\end{array}$ \\
\hline Female & $\begin{array}{c}.422 \\
(.074)\end{array}$ & $\begin{array}{l}.050 * \\
(.035)\end{array}$ \\
\hline Part-time & $\begin{array}{c}.022 \\
(.022)\end{array}$ & $\begin{array}{c}.050 \\
(.035)\end{array}$ \\
\hline \multirow[t]{3}{*}{ Single shift } & $\begin{array}{c}.956 \\
(.031) \\
\end{array}$ & $\begin{array}{l}.700 * \\
(.073) \\
\end{array}$ \\
\hline & \multicolumn{2}{|c|}{ Firm 22537} \\
\hline & Control plant & Treatment plant \\
\hline Age & $\begin{array}{l}35.62 \\
(.575) \\
\end{array}$ & $\begin{array}{l}36.78 \\
(.498) \\
\end{array}$ \\
\hline Job complexity & $\begin{array}{l}35.66 \\
(.133)\end{array}$ & $\begin{array}{l}35.92 \\
(.132)\end{array}$ \\
\hline Industry tenure & $\begin{array}{l}12.72 \\
(.609) \\
\end{array}$ & $\begin{array}{l}12.39 \\
(.441) \\
\end{array}$ \\
\hline Female & $\begin{array}{c}.053 \\
(.013)\end{array}$ & $\begin{array}{c}.033 \\
(.009) \\
\end{array}$ \\
\hline Part-time & $\begin{array}{c}.059 \\
(.013) \\
\end{array}$ & $\begin{array}{l}.016^{*} \\
(.006) \\
\end{array}$ \\
\hline \multirow[t]{3}{*}{ Single shift } & $\begin{array}{c}.388 \\
(.027) \\
\end{array}$ & $\begin{array}{l}.617^{*} \\
(.024)\end{array}$ \\
\hline & \multicolumn{2}{|c|}{ Firm 13572} \\
\hline & Control plant & Treatment plant \\
\hline Age & $\begin{array}{l}31.62 \\
(.180) \\
\end{array}$ & $\begin{array}{c}41.32 * \\
(.456) \\
\end{array}$ \\
\hline Job complexity & $\begin{array}{l}33.77 \\
(.038) \\
\end{array}$ & $\begin{array}{l}33.93 \\
(.103)\end{array}$ \\
\hline Industry tenure & $\begin{array}{c}5.00 \\
(.012)\end{array}$ & $\begin{array}{c}10.07 * \\
(.310)\end{array}$ \\
\hline Female & $\begin{array}{c}.479 \\
(.010) \\
\end{array}$ & $\begin{array}{c}.503 \\
(.020) \\
\end{array}$ \\
\hline Part-time & $\begin{array}{c}.017 \\
(.003)\end{array}$ & $\begin{array}{c}.009 \\
(.004)\end{array}$ \\
\hline \multirow[t]{3}{*}{ Single shift } & $\begin{array}{c}.213 \\
(.008) \\
\end{array}$ & $\begin{array}{l}.997^{*} \\
(.002)\end{array}$ \\
\hline & \multicolumn{2}{|c|}{ Firm 13320} \\
\hline & Control plant & Treatment plant \\
\hline Age & $\begin{array}{l}42.21 \\
(.315)\end{array}$ & $\begin{array}{c}39.61 * \\
(.980)\end{array}$ \\
\hline Job complexity & $\begin{array}{l}36.22 \\
(.720)\end{array}$ & $\begin{array}{l}34.00^{*} \\
(.174)\end{array}$ \\
\hline Industry tenure & $\begin{array}{l}17.37 \\
(.274) \\
\end{array}$ & $\begin{array}{c}10.58^{*} \\
(.942)\end{array}$ \\
\hline Female & $\begin{array}{c}.022 \\
(.006) \\
\end{array}$ & $0^{*}$ \\
\hline Part-time & $\begin{array}{c}.017 \\
(.005)\end{array}$ & $\begin{array}{c}.024 \\
(.014)\end{array}$ \\
\hline Single shift & $\begin{array}{c}.168 \\
(.015)\end{array}$ & $\begin{array}{c}.200 \\
(.036)\end{array}$ \\
\hline
\end{tabular}

NOTES: Standard errors are in parentheses. A * denotes that the treatment characteristic is statistically different from that of the control. 
